\title{
Drømmen om et Kurdistan
}

\section{Thure Krarup}

Den kurdiske region har etableret sig som Iraks succeshistorie. Her er sikkerhed, økonomisk vækst og politisk stabilitet, hvilket har givet næring til drømmen om en selvstændig kurdisk stat. Fremtiden for den plagede kurdiske befolkningsgruppe er dog langt fra sikker i et Irak, hvor hensynet til kurderne meget vel kan drukne i landets politiske kaos og storpolitiske overvejelser

Passagererne i Austrian Airlines Flight OS829 fra Wien til Erbil i det nordlige Irak passer ikke rigtigt sammen. Dansk-irakere i træningsdragter, højtråbende amerikanske soldater og forretningsmænd med vestlige og arabiske pas i nypressede jakkesæt. Jeg er lidt urolig. Jeg har været i Irak før, men da var det iført uniform og med et skarpladt våben hængende ned langs siden. OS829 lander, og skiltet over ankomsthallen proklamerer 'Welcome to Kurdistan'. Jeg sætter mig ind i en spritny gul taxa og kører gennem rolige gader og nydelige kvarterer mod mit hotel. Det føles ikke som Irak, og det er det egentlig heller ikke.

Kurdistan eksisterer ikke, men
'Irakisk Kurdistan', som er regionens officielle navn, er det tætteste kurderne nogensinde har været på en stat. Det er Iraks kurderes region, som både er mentalt og fysisk afsondret fra det øvrige Irak. De kalder det selv 'Det Andet Irak'.

Kurderne er den af Iraks befolkningsgrupper, der har lidt hårdest under Saddam Husseins regime. Kurderne blev brutalt undertrykt, og nogle af Saddams grusomste forbrydelser blev begået mod kurderne. Giftgasangreb, deportationer, tortur og politisk undertrykkelse er alle elementer i en nær fortid, som kurderne har lagt bag sig, men ikke har glemt. Kurderne har gennem al historisk tid følt sig svigtet og under- 
trykt af arabere, europæiske kolonimagter, amerikanere, tyrkere og iranere, og mistroen til især Iraks arabiske grupper har levet videre. Det kurdiske dilemma er en uløst problematik i det internationale samfund om verdens største nation uden en stat. En debat, der ofte er blevet ignoreret, men som har fået fornyet relevans efter invasionen af Irak.

\section{En ny start}

Invasionen af Irak i 2003 gav kurderne en ny start, og siden da har Irakisk Kurdistan været et område præget af fremskridt. Det er ingen tilfældighed, at det er den kurdiske region, der bliver fremhævet, når statsledere fra Bush til Fogh skal fremhæve positive historier fra det irakiske kaos. Irakisk Kurdistan er et område, der har været plaget af Saddams undertrykkelse og en intern borgerkrig, og som har rejst sig politisk og $\varnothing$ konomisk efter det tidligere regimes fald. Det er den perfekte historie om berettigelsen af invasionen af Irak. Men kurderne balancerer lige nu mellem himmel og helvede. Mellem en kurdisk region, der har oplevet store fremskridt og en irakisk stat, der er ramt af anarki og kaos. Mellem kurdernes drømme og Iraks realiteter.

Kurderne har som gruppering ofte været overset i debatten om det irakiske magtopgør og kampen om Iraks fremtid som stat, idet der har været en tendens til udelukkende at fokusere på den sekteriske magtkamp mellem Iraks sunni- og shi'agrupperinger. Det er imidlertid en grov fejltagelse at udelade den stærke og homogene kurdiske befolkningsgruppe af denne ligning. Kurderne vil i lige så høj grad som Iraks arabiske grupper komme til at determinere Iraks fremtid og enhver debat omkring den irakiske konflikt er nødt til at tage højde for den kurdiske faktor.

Denne artikel vil på den ene side forklare baggrunden for den positive udvikling i den kurdiske region og på den anden side se på fremtidsperspektiverne for Iraks kurdere og de udfordringer kurderne står overfor i et Irak på randen af borgerkrig.

\section{Fra borgerkrig til politisk forsoning}

Efter pres fra det internationale samfund opnåede den kurdiske region i Irak de facto-autonomi i 1991. Saddams straf for et kurdisk oprør i kølvandet på Iraks invasion af Kuwait og den efterfølgende krig med den vestlige koalition var skånselsløs, og de globale nyhedsmediers dækning af op imod en million fordrevne kurdere på flugt tvang Vesten til at handle.

Kurderne blev tildelt selvstyre over de tre kurdiske provinser (Erbil, Suleymaniya og Dohuk) i det nordlige Irak og de to primære politiske partier, PUK og KDP, dannede samlingsregeringen Kurdish Regio- 
nal Government (KRG). De to partier havde imidlertid svært ved at dele magten mellem sig, og en bitter borgerkrig mellem de to partier udspillede sig i midten af 1990'erne.

Ifølge kurderne selv var borgerkrigen et nødvendigt onde, der lærte de politiske partier den absolutte nødvendighed af at samarbejde og skabe kompromiser om den politiske kurs. Kurderne har taget deres interne magtkamp og var ved invasionens start den eneste af Iraks grupper, der havde en fungerende politisk organisation.

Perioden efter invasionen har været kendetegnet ved en høj grad af politisk stabilitet i Irakisk Kurdistan. Den irakiske forfatning har tildelt kurderne retten til at bibeholde en høj grad af politisk autonomi, og lovgivningsarbejdet og den politiske genopbygning i den kurdiske region er nået langt. Et væsentligt element i denne genopbygning har været den stadigt større sammensmeltning og politiske forsoning mellem de to altdominerende partier, PUK (ledet af Jalal Talabani) og KDP (ledet af Nechirvan Barzani). Foreningen af det politiske system giver kurderne en betydelig fordel såvel i bekæmpelsen af regionens interne problemer som i magtspillet med Iraks arabiske befolkningsgrupper.

Der er enighed mellem partierne omkring de overordnede politiske strategier og stor opbakning bag den politiske ledelse i KRG. Der er derudover gjort en stor indsats for at professionalisere det politiske system og lade teknokrater overtage administrative poster fra partimedlemmer. Til dette formål har man i særdeleshed gjort brug af personer fra den kurdiske diaspora.

Kurdere fra hele verden er vendt tilbage for at deltage i den politiske genopbygning af den kurdiske region. De medbringer vigtige uddannelsesmæssige kompetencer og forståelse for den praktiske udøvelse af demokratisk styre.

Gruppen af professionelle embedsmænd og akademikere i regionen vokser derfor støt, og denne gruppe udgør den 'lærde middelklasse', som traditionelt er fundamentet for en velfungerende politisk organisering, men som er fraværende i resten af Irak.

De to partier har vedtaget en funktionel arbejdsdeling i den praktiske udøvelse af det politiske lederskab. Mens Jalal Talabani blev valgt til posten som Iraks præsident og officielle statsoverhoved, fik Nechirvan Barzani posten som premierminister for KRG og politisk leder af Irakisk Kurdistan. Alle væsentlige politiske poster er derudover fordelt ligeligt mellem partierne. Nechirvan Barzani beskrives som en moderne leder med et stort talent for forhandling, og han er med til at tegne billedet af den kurdiske politiske elite, der beskrives som pragmatiske, rationelle og kompromissøgende.

Mens ikke alle politiske fraktioner i Irak deler denne opfattelse, er der 
nærmest utvetydig opbakning bag den politiske ledelse fra den kurdiske befolkningsgruppe i Irak. De kurdiske politikere nyder - i modsætning til de sunni- og de shi'amuslimske politikere - deres befolknings støtte og tillid. Kurderne selv forklarer det med, at de kurdiske politikere er vokset ud af befolkningen. De har spildt deres eget blod for Kurdistan og den kurdiske sag, som en minister i KRG udtrykte det.

\section{Fortsatte udfordringer}

Den klart definerede politiske elite, afklarede interne magtforhold, befolkningens opbakning, reel erfaring med demokratisk styre og et politisk sindelag, der er mere teknokratisk og sekulært end de øvrige irakiske fraktioner udgør de primære faktorer, der forklarer de politiske fremskridt i Irakisk Kurdistan og kurdernes store indflydelse på det politiske spil i Bagdad.

Kurderne søger at anvende denne indflydelse til på den ene side at holde sig uden for den sekteriske magtkamp mellem Iraks arabiske grupper og indtage en neutral mæglerrolle mellem disse parter, og på den anden side at stå stejlt på de kurdiske mærkesager. De primære kurdiske mærkesager er - ud over en opretholdelse af den kurdiske regions politiske autonomi - en retfærdig fordeling af indtægterne fra Iraks olie samt en løsning på den delte by Kirkuks fremtidige status.
Især sidstnævnte er et sprængfarligt politisk emne, der udgør den pt. mest kritiske udfordring for kurdernes forhandlinger med Iraks arabiske grupper. Kurderne anser Kirkuk for at være deres hovedstad og gør demografisk og historisk krav på byen, der blev 'tvangsarabiseret' under Saddams styre. De enorme oliereservoirer i området omkring byen og dens uhomogene befolkningsmæssige karakter gør imidlertid spørgsmålet om byens fremtid politisk følsomt og gør byen til en oplagt scene for sekterisk vold.

Kirkuk vurderes af flere kilder som værende Iraks pt. farligste by. Ifølge den irakiske forfatning skulle spørgsmålet om Kirkuks fremtidige status have været afgjort ved en folkeafstemning blandt byens indbyggere inden udgangen af 2007, men er druknet i det ineffektive lovgivningsarbejde i Bagdad. En løsning på Kirkuk-spørgsmålet er kurdernes absolut vigtigste politiske prioritet, og det er ved dette spørgsmål, at kurdernes pragmatisme forvandles til stejl nationalistisk idealisme.

På trods af områdets politiske stabilitet og fremskridt har Iraks kurdere fortsat store politiske udfordringer foran sig, både på den interne og den eksterne front.

Internt kritiseres den politiske ledelse for at udøve ekstrem politisk topstyring. Den politiske magt er koncentreret ikke blot omkring ledelsen i PUK og KDP, men omkring områdets to magtfulde familier fra 
Talabani-slægten og Barzani-slægten. Der er således langt fra tale om vestlige forestillinger om demokratiske tilstande, og systemet er hermetisk lukket for folk uden tilknytning til den politiske elite, ligesom dialog med befolkningen eller civilsamfundet er ikke-eksisterende. De lovgivende og dømmende institutioner er ligeledes blevet udsat for hård kritik for udbredt nepotisme, korruption og ineffektivitet. Det lovgivningsmæssige apparat i regionen er trods den partimæssige forsoning fortsat splittet mellem partierne.

På overfladen er størstedelen af ministerierne forenede og partimæssigt uafhængige, men i praksis finansieres og kontrolleres de direkte af enten PUK eller KDP. Systemet er dybt uøkonomisk, hvilket tydeliggøres af, at 63 procent af den kurdiske regions budget går til offentlige lønudgifter. Systemet skal rationaliseres, og de mange offentlige embeder der udelukkende skyldes nepotisme og familieaftaler og ikke bunder i reelle kvalifikationer, skal skæres væk. Det politiske klima er ud over partisplittelsen præget af et sammenstød mellem et forældet, bipolært system, der er et levn fra borgerkrigen, og en mere liberal og moderne tankegang som den lærde middelklasse er eksponenter for.

Eksternt har kurderne været udsat for kraftig kritik fra både lokale og regionale aktører. Regionalt er den største udfordring KRG's konflikt med Tyrkiet vedrørende den tyrkisk- kurdiske separatistbevægelse PKK, der opererer fra bjergene $\mathrm{i}$ det nordlige Irak og gennemfører raids ind i Tyrkiet.

Tyrkiet har de seneste måneder haft en enorm hærstyrke opmarcheret ved den tyrkisk-irakiske grænse og tyrkiske bombefly har ved flere lejligheder krydset grænsen for at ramme PKK's lejre. I februar gennemførte Tyrkiet den første landoperation ind i det nordlige Irak, hvilket fra de irakiske kurderes side blev mødt med kritik og en appel til verdenssamfundet om, at nabostater skulle respektere Iraks suverænitet. Operationen blev imidlertid accepteret af USA, hvorfor kurderne i realiteten var magtesløse og var tvunget til at se passivt til, mens den tyrkiske hærstyrke bevægede sig ned igennem den kurdiske region.

Tyrkiet har ved flere lejligheder kritiseret KRG for stiltiende at acceptere PKK's tilstedeværelse i regionen og dermed for at billige terror. KRG's svar på denne kritik har konsekvent været, at KRG ikke har indflydelse på PKK, og at konflikten er et internt tyrkisk anliggende. KRG er dog tvunget til at agere med stor varsomhed velvidende, at ethvert kurdisk ønske om autonomi afhænger af forholdet til naboen mod nord, ligesom Tyrkiet er kurdernes vigtigste handelspartner og regionens adgangsvej til det vestlige marked. En militær reaktion fra KRG er derfor ikke en mulighed, og så længe Tyrkiet indskrænker sine angreb 
til at omfatte de øde bjergregioner langt fra kurdernes større byer, vil man være ude af stand til at reagere på Tyrkiets anslag mod regionen, ligesom man i praksis ikke vil have nogen interesse heri.

Dette blev tydeliggjort under den seneste konflikt, hvor Jalal Talabani på tyrkisk TV erklærede, at PKK var en terroristorganisation, og at KRG ikke havde problemer med den tyrkiske landoperation - så længe den var rettet alene mod at fjerne truslen fra PKK. Dette var en klar afvigelse fra den hidtidige retorik og en eksplicit anerkendelse af at kurderne prioriterer et godt forhold til Tyrkiet højere end en nyttesløs moralsk støtte til de tyrkisk-kurdiske landsmænd fra PKK, og endnu et eksempel på at den politiske ledelse i Irakisk Kurdistan på pragmatisk vis prioriterer sine kampe med omhu.

Kritikken i den interne irakiske debat er primært kommet fra sunnimuslimske politiske og religiøse grupper. Sunnitterne kritiserer kurderne for i flere tilfælde at gå politisk enegang og agere uden konsultation med den irakiske regering, ikke mindst i forbindelse med fordelingen af Iraks olie, hvor kurderne selvstændigt har underskrevet flere kontrakter med udenlandske firmaer og vedtaget sin egen regionale olielovgivning. Dermed har kurderne marginaliseret den irakiske regering og bidraget til dennes splittelse.

Kurderne og sunnitterne har vidt forskellige idealer om Iraks fremtid som stat. Sunnitterne ønsker først og fremmest at bevare Irak som en samlet stat med en stærk politisk og økonomisk centralisering omkring Bagdad og ser derfor kurdernes krav om vidtgående autonomi som en forløber for en reel opsplitning af staten. Kurderne har siden invasionen været amerikanernes tætteste allierede og bidraget til, hvad der af mange opfattes som forsøget på at gøre Irak til en vestligt domineret koloni, hvilket i nogle kredse har givet dem tilnavnet 'Iraks jøder'. Analogien mellem Irakisk Kurdistan og Israel er blevet fremført af flere fremtrædende sunni-muslimske organisationer, og ikke kun i Irak.

\section{Iraks sikre oase}

Kurderne har erkendt, at sikkerhed er den væsentligste forudsætning for genopbygningen af Irak og for at opnå fremskridt på den politiske og økonomiske front. Derfor er den sikkerhedsmæssige opgave, der ligger $i$ at isolere området og afskærme den kurdiske region mod import af det irakiske kaos prioriteret meget højt. Udlændinge og investorer skal kunne føle sig trygge i den kurdiske region, fordi ingen udenlandske firmaer vil investere i regionen og ingen fra Vesten vil besøge området, hvis man har en frygt for, at man som virksomhed vil være et mål for terrorister.

Den kurdiske region skal kunne bevise, at den er sikkerhedsmæssigt 
stabil og helt forskellig fra det øvrige Irak. Og kurderne har haft succes med denne bevisførelse. Alle statistikker placerer den kurdiske region som Iraks absolut sikreste område, og eksempelvis har regionens hovedstad, Erbil, kun været udsat for to mindre terroranslag i de seneste tre år. Terroraktioner rettet mod civilbefolkningen anses af de kurdiske myndigheder ikke længere for at være en reel risiko, og man føler sig faktisk tryg, når man vandrer rundt $\mathrm{i}$ Erbil.

Den væsentligste årsag til denne succes er, at kurderne har haft held til at forsegle Irakisk Kurdistans grænser fra Iraks arabiske regioner. Der er ekstreme sikkerhedsforanstaltninger i form af stærkt bemandede checkpoints ved alle indfaldsveje til den kurdiske region. Man frygter araberne, og alle biler og personer, der krydser grænsen til den kurdiske region, bliver ransaget grundigt, især hvis bilen har arabisk indregistrering. Ingen arabere kommer ind i Irakisk Kurdistan, medmindre de kan fremvise en arbejdstilladelse til den kurdiske region eller en skriftlig invitation fra en kurdisk statsborger.

Derudover har man hele vejen rundt om regeringsbyen Erbil gravet en middelalderinspireret voldgrav. Tre meter dyb, tre meter bred og 91 kilometer i diameter sikrer den kurderne mod uvelkomne gæster, der prøver at undgå de almindelige veje. De kurdiske sikkerhedsstyrker pa- truljerer massivt i de største byer og langs grænsen til det øvrige Irak. I modsætning til de irakiske sikkerhedsstyrker er kurdernes såkaldte Peshmerga-styrker fuldstændigt loyale over for den kurdiske sag og dybt respekterede af lokalbefolkningen.

Denne loyalitet betyder også, at efterretningsarbejdet i regionen er yderst effektivt. Der er klare markører på hvem der er kurder, og hvem der ikke er - tøj, sprog, ansigtstræk - og tilstedeværelsen af ukendte eller suspekte personer bliver anmeldt til den kurdiske efterretningstjeneste. Systemet fungerer.

Iraks slagmarker er imidlertid aldrig langt væk, og i Mosul og Kirkuk langs den kurdiske grænse er kurderne tilbage i den offerrolle, de så ofte har været i. Der er flere - i særdeleshed sunniarabiske - militsgrupper, der specifikt retter deres angreb mod kurdere med det mål at trække kurderne ind i den sekteriske konflikt i Irak. Kombineret med en opmarcheret tyrkisk hærstyrke og med aggressive nabostater som Syrien mod vest og Iran mod øst, er Irakisk Kurdistan fortsat ikke helt den turistdestination, som de ønsker at blive.

\section{Byggeboom og økonomisk ulighed}

På den økonomiske front har den kurdiske region ligeledes udviklet sig til en anomali i forhold til det øvrige Irak. Man har haft held til at tiltrække investeringer fra udenlandske firmaer og har indgået store 
og yderst lukrative kontrakter med firmaer fra Tyrkiet, Norge, Canada og Dubai om prøveboringer og udvinding af nye oliefelter i området. De fleste meldinger går på, at regionen har vækstrater i BNP på omkring 10 procent per år.

Resultatet af de stigende udenlandske investeringer har været et sandt byggeboom og en ekstrem optimisme for områdets økonomiske fremtid. Nye luksuriøse boligområder, indkøbscentre, universiteter, hospitaler og hoteller skyder op som paddehatte overalt. Eksklusive boliger skal lokke udlændingene og investorer fra de arabiske stater til at slå sig ned i området. Tre nye femstjernede hoteller skal trække turister til. En ny lufthavn skal gøre adgangen til området nemmere. Der er planer om store barer og et kasino. 'Dubais lillesøster' kalder direktøren for områdets indtil videre eneste femstjernede hotel Irakisk Kurdistan.

Men ikke alle kurdere har nydt godt af den positive udvikling. Uligheden er stigende, den generelle levestandard lav og arbejdsløsheden høj. Langt størstedelen af befolkningen har ikke fået del i boomet, og der er stigende kritik af KRG for ikke at gøre den almindelige kurders liv synligt bedre. For at bruge pengene på prestigebyggerier frem for at forbedre elektricitetsforsyningen, sundhedssektoren, infrastrukturen og vandforsyningen. Velfærdsstigningen er primært koncentreret omkring en nyrig overklasse i de største byer, og det bliver en meget stor udfordring for KRG at bryde dette mønster. Mønsteret skal imidlertid brydes, hvis de fortsat ønsker den brede befolknings utvetydige støtte.

Den klart væsentligste indtægtskilde for den kurdiske region er fortsat den del af Iraks olieindtægter, der tilfalder regionen. Udformningen af en fælles irakisk olielovgivningen har udgjort en bitter konflikt mellem Bagdad og kurderne og gør det stadig. Blodsudgydelse i Irak drejer sig altid i en eller anden grad om Iraks sorte guld.

Kurderne har i forhandlingerne krævet 17 procent af Iraks olieindtægter og dette ønske er indtil videre blevet accepteret, men kurdernes krav om decentralisering af kontrollen med olien og deres ret til selvstændigt at forhandle kontrakter med udenlandske oliefirmaer er fortsat kilde til stor vrede hos de arabiske forhandlingspartnere. Den fælles irakiske olielov er fortsat ikke vedtaget i det irakiske parlament, og mens kurderne fortsætter med at agere unilateralt på området, synes et kompromis længere og længere væk.

\section{Drømmen}

Alle kurdere indrømmer, at den store nationale drøm er et selvstændigt Kurdistan. Der er imidlertid forskel på forestillingerne om, hvilket terri- 
torium denne stat skal grundlægges på. Den kurdiske befolkningsgruppe i Irak er primært mobiliseret omkring ideen om en kurdisk stat inden for Iraks grænser frem for den mere hardline kurdiske nationalismes ide om et Stor-kurdistan, der også inkluderer kurdisk dominerede områder i nabolandene Tyrkiet, Iran og Syrien.

Den kurdiske befolkning opfatter først og fremmest sig selv som kurdere og kun i meget begrænset grad som irakere, og de ønsker et Irakisk Kurdistan, der i praksis er uafhængigt af Bagdad, og ultimativt en selvstændig kurdisk stat. Et ønske, der blev understreget ved en uofficiel afstemning om kurdernes fremtidige status i Irak i januar 2005, hvor over 90 procent af den kurdiske befolkning stemte for kurdisk selvstændighed.

Den kurdiske nationalfølelse er ekstremt fremtrædende overalt i den kurdiske region, og nationale symboler som det kurdiske flag, billeder af de kurdiske ledere Barzani og Talabani og kort over den kurdiske 'stats' territorium ses overalt. Irakiske flag har indtil for ganske nylig været forbudte i regionen, og det arabiske sprog findes hverken i tale eller skrift blandt de lokale.

Kurderne støtter dog fortsat op om den politiske linje som KRG har udstukket, og som indebærer at Irakisk Kurdistan forbliver en del af den irakiske stat, men har en høj grad af politisk selvbestemmelse i et
Irak, der er styret efter en decentraliseret føderal model.

\section{Kurdernes fremtid i Irak}

Kurdernes fortid i Irak har været karakteriseret ved undertrykkelse og mistro til den irakiske stat.

Det kurdiske projekt i Irak er derfor at opbygge en holdbar, selvstyrende politisk enhed i de tre kurdiske provinser i Irak - i realiteten et statsbygningsprojekt. Det har det været siden kurderne i kølvandet på den første Golfkrig opnåede de facto-autonomi i 1991.

Kurderne har ikke en stat, og det er ikke den officielle strategi at stræbe efter en stat, men erkendelsen fordret af kurdernes historie og Iraks nuværende kendsgerninger er, at kurderne må stræbe efter at opbygge de strukturer, der karakteriserer en stat. Håbet er, at de realpolitiske vinde på et tidspunkt vender, og det internationale samfund vil overveje berettigelsen af en kurdisk stat. Man har erkendt, at et selvstændigt Kurdistan i den nuværende situation ikke er en mulighed, hvorfor kurderne har stillet sig tilfreds med - for nu - at være en del af et føderalt Irak.

Kurderne bliver aldrig irakere, og kravet for at vedblive en del af Irak er, at man bibeholder en høj grad af politisk selvbestemmelse, og at de kurdiske mærkesager om en løsning på Kirkuk-problematikken samt en retfærdig fordeling af indtægterne 
fra Iraks olie tages alvorligt i Bagdad. Kurderne skal søge en balance mellem at realisere deres egne drømme og undgå at ignorere Iraks problemer som stat. En balance mellem en insisteren på de kurdiske ambitioner og en nødvendig tålmodighed i relationerne med et splittet Bagdad.

De kurdiske krav til et fremtidigt Irak og de politiske prioriteringer, som kurderne opfatter som presserende, er imidlertid blot ét element af en debat, der involverer langt større konflikter og langt stærkere aktører end kurderne. Den stemme, der opfatter kurderne som en agent provocateur - en provokatør med det ene formål at splitte Irak op og erklære sig selvstændige - er magtfuld.

Tyrkiet og Iran frygter en kurdisk stat af frygt for oprør blandt landenes store kurdiske mindretal. Iraks sunni-muslimer frygter en disintegration af den irakiske stat, da det område, hvor de udgør majoriteten, er afskåret fra Iraks olie, og de støttes af magtfulde sunni-muslimske stater som Saudi-Arabien.

USA og Vesten deler muligvis en sympati for den kurdiske sag, men er primært interesserede $i$ at forbedre sikkerhedssituationen og skabe en bred politisk forsoning mellem Iraks befolkningsgrupper, der vil kunne retfærdiggøre en militær tilbagetrækning og lukke en sag, der absolut ikke er indenrigspolitisk go- odwill i længere. Storpolitisk og regional hensyntagen til at undgå en irakisk borgerkrig og opretholde Iraks territorielle integritet vil derfor utvivlsomt veje tungere end hensynet til Iraks kurdere.

Debatten om Irak involverer enorme politiske interesser og indsatser og risikoen for, at kurderne endnu engang vil ende som offer i et storpolitisk spil, er derfor absolut til stede.

For Iraks kurdiske befolkningsgruppe kolliderer fortidens undertrykkelse med drømmene og håbet for fremtiden i nutidens politiske debat. Kurdernes skæbne bliver i sidste ende afgjort af den vanskelige og uforudsigelige balancegang mellem den realpolitiske pragmatisme og opportunisme knyttet til Iraks realiteter og idealismen knyttet til et mishandlet folks drømme.

En balancegang, hvor kurderne lige så godt kan blive tabere som vindere.

Thure Krarup er cand. scient. pol. Han har skrevet speciale om kurderne i Irak, og $i$ den forbindelse gennemførte han et feltarbejde i Erbil, hvor han bl.a. interviewede en lang rekke politikere og embedsmand $i$ den kurdiske regionalregering, KRG. Thure Krarup er desuden sprogofficer $i$ arabisk og har varet udsendt med Forsvaret til Irak $i$ 20052006. 